\title{
Port of Patimban as A Solution to Fulfill the Capacity Demand of Port Terminal in Indonesia
}

\author{
Johny Malisan \\ Center for Research and Development on Sea Transportation - Indonesia
}

\begin{abstract}
Seaport as a part of transport chain and logistic system has a very important role and strategic for economic growth and development. Besides, it seemed sensible to exploit the synergies between ports and must be linked to their hinterland. To stimulate economic activity and realize an efficient logistic cost, the government's effort to create a healthy business climate and competitiveness through the development of a new port is one solution. This research aimed to analyze the port infrastructure that will be developed and to analyze port capacity that is still limited and should be developed in order to address the main issues that emerged at the port, i.e. congestion and dwell time. The results showed that although existing port has been developed, it seems quite difficult to handle high volume of container traffic in the future, which until 2050 predicted will reach average more than 20 millions TEUs per year. Synergy with port of Patimban is one way to fulfill capacity demand of port terminal. Indonesia has not yet emerged as a logistics hub and the most important factor is poor condition of port infrastructure. Therefore, it is required to change the pattern of container handling by pursuing the development of new port in order to avoid stagnation, congestion and dwelling time.
\end{abstract}

Keywords: limited port capacity, port development, efficient logistic cost.

\section{INTRODUCTION}

Indonesia is an archipelago and it is primarily dependent on sea transport thus the development of seaport is crucial to facilitate economic growth [1]. Seaport as an infrastructure of transportation and a part of logistic chain system is very important and strategic for industrial growth and trading as well as a business segment contributed to national economy and development. Seaport is also an essential part of the maritime transport industry and has a key role within integrated transport chains (Cullinane in [2]). Therefore, port should be managed effectively, efficiently, and professionally. Infrastructure development can increase an access to many resources that improve their productivity which in turn to drive economic growth. The large potential resources of Indonesia that requires transport facilities for accelerating access to consumers. The existence of the port has an impact on economic development around the port, so not only benefit investors but also the government and national or international communities. Seaport benefits can be considered as a driving force for a sound economic justification of expansionary goals for ports activities [3]. Many studies indicated how important the role of port infrastructure in economic growth, poverty reduction, creation of employment, and even specifically develop agricultural and industrial sectors. Besides, seaports could also be significant nodes in the transport and logistic chains that form the backbone of national and regional economy [2].

In this globalization era and fast expansion of world trade, seaport become major node in supply chain and logistic process; act as a transport hub with other intermodal transport network road, rail and inland waterways. Lately, main problem frequently encountered is that trade development is not in line with the provision of transport infrastructure which result in port congestions. Congestion brings delays for port users and increases costs to stakeholders such as shipping lines, terminals (yard congestion, re-handling), trucking companies and railways (longer waiting time) and shippers (Mabs in [4]). For major case in Indonesian congestion is partly due to the provision of the inadequate sea transport infrastructure. According to Greg Knowler [5], in Indonesia the problems being faced by the container terminal industry are the exact opposite there are not enough dedicated container facilities and terminal berths. Examples this case is flow of export containers from port of Tanjung Priok is increasing each year, i.e. 5.9 million TEU's in 2011, 6.4 million TEU's in 2012 and 8 million TEU's in 2013 and will continue to develop due to currently growth of export and import goods. Capacity this port could only accommodate 7 million TEU's per year [6].

Dekker et. al. (in Adris.A.Putra [7]) stressed that infrastructure development through the expansion of capacity will have a positive impact on the national and regional economic development. Expansion of capacity could be carried out by developing ports in neighbor regions to mutually cooperate in handling the cargoes development. Looking currernt condition of port of Tanjung Priok which has been already crowded, it is necessary to build an alternative port, and government established Patimban in West Java as a representative location remedy in order to reduce congestion. It is vert important because of dealing directly with Malacca and 
Singapore Straits, international shipping routes and interconnection of port of Tg.Priok with other ports in international economic regions such as AEC and APEC. Moreover, APEC composed of 21 countries of AsiaPacific is now controling most of the world economies, its population reached $40 \%$ of the world's population, to cope with 55\% of world GDP and $44 \%$ of world trade activities comes from APEC countries [8]. To benefit these opportunities and to increase port capacities, government encouraged the development of Patimban Port, reinforced by issuing Presidential Regulation No. 47 Year 2016 concerning the establishment of Patimban Port in Subang Regency of West Java province as a national strategic project. It is expected that this expansion of port capacity will increase the flow of goods, services and access of potential areas as driving economic growth. Enhancement of transport infrastructure in West Java is expected to be a stimulant for increased investment, both domestic and internasional. The availability of well transport infrastructure and intermodal connected by road and rail is believed to be able to spill-over investment from other regions to the West Java especially Subang Regency. Currently, Indonesia still lacks capacity of port so that often encountered congestion which contributes to the high cost of logistics. Therefore, alternative solution should be formulated to overcome the problem through research potential port of Patimban and determine its development in the future.

\section{THEORITICAL FRAMEWORK}

\section{Connectivity}

Connectivity system in the archipelagic region should be strengthened that relationship within the islands and inter-islands can proceed smoothly to support their economic development. Connectivity strengthening aims to expand economic development to the surrounding areas, especially to underdeveloped, remote and border areas [9]. Connectivity system is the connection between one component or activity with others which are supported by well transport facility and infrastructure. Building connectivity in the document of national logistic system has a vision which is locally integrated and globally connected and has 3 (three) levels of integrated connectivity namely local connectivity (intra-island), national connectivity (inter-island) and global connectivity (international). In the archipelago, scenarios of connectivity is needed for obtaining goals of regional development. One of the national connectivity frameworks factors, i.e. National Transportation System, shows that transportation infrastructure plays an important role in serving communitiesdemand and gives a multiplier function as a support element and development driving. According Wagijono [10] national transportation system is an artery of transportation, driving and supporting the development of all economic sectors. Therefore, the need of connectivity should be a priority by the arrangement or umprovement of intra or inter-island transport dealing with the high cost of transportation, weak competitiveness and poverty reduction which is relatively slow. System of connectivity is expected to disclose isolated and remoted areas. The main objective of improving connectivity is to reduce prices and services disparities, increase competitiveness, which will finally accelerate poverty eradication and increase social and economic accessibility.

Economies of scale and connectivity should be still considered in the development of the transport network. Conceptually, a transport network is simply a set of links and nodes that are interconected, and there are also interactions between transport and the economy [11]. Therefore, in view of industrialization complexity in West Java it was needed the development of environmental friendly transport infrastructure, safe and convenient that could accommodate economic activity. The existing port is currently not sufficient to accommodate those problems, that's why practitioners mentioned that government should act as supervisors regularly monitor the implementation of all strategies that have been agreed and implemented and supervised the healthy competition that occurs in the business of port.

\section{Port}

As part of the transport and logistic chain, port function is interface of two or more transport modes and various interests interrelated. But if we look at the facts, we must admit that many ports in Indonesia still not managed properly. Besides, the low network density as well as the unreliable and poor access to existing network has hindered the poverty eradication and growth in the isolated remote areas [12]. The competitiveness of ports in Indonesia is still weak and according to the Global Competitiveness Report 2009-2011, of 134 countries, the competitiveness of Indonesian ports was rank of 95, higher than in 2008, which achieved $104^{\text {th }}$. That position was still low if compared with Singapore, Malaysia, and Thailand. That port weakness lies in the quality of their infrastructure and superstructure.

The feasibility study conducted Faculty of economi University of Indonesia (2010), by citing data of Global Competitiveness Report found out that between 134 countries Indonesia was ranked of 104, loading and unloading productivity is still low (40-45 containers per hour, while port of Singapore and Malaysia about 100 110 containers per hour). In addition, the problems being faced by the container terminal industry in Indonesia are there are not enough dedicated container facilities and terminal berths [5]. World Bank data showed that in 
year 2000 container through put were 3,797,948 TEU's and in 2014 to be 11,900,763 TEU's. Therefore, according to Syafi'i [13] such a high through put has compelled the improvement port performance and facility, and the construction of new port. Oxfrod Business Group [14] stated that as the biggest container port in Indonesia, Tanjung Priok is the country's largest international container terminal and handles 65\% of its entire cargo trade, it is extremely congested and its performance lags behind that of most other major ports in Southeast Asia. The port capacity is getting smaller though new infrastructure has been built so that the government considered to relocate to other areas by setting Patimban as a new strategic location. Transport Minister said that port of Patimban would able to handle 7.5 million TEU's of containers and accommodate 250,000 cars. The government of course played an important role in providing access to basic needs of individual communities safely, consistent with health and eco system as well as social wellfare which arranged in a sustainable transport system [15].

\section{RESULTS AND DISCUSSION}

\section{Geographical location of the Port Patimban and economic growth}

Port of Patimban is a port that has been agreed to be built by the government, located in Subang Regency, West Java Province of Indonesia. This port will be functioned as a major port that will be enabled to anticipate the lack of the existing ports in handling imports and exports container cargoes. Document of Patimban Port Development Plan informed that its land area is 3,123,790.18 square meter. Geographically Port of Patimban is low-lying area and two-third of its area are fisheries and agricultural land so that majority of its populations are fishermen and farmers. Besides, there is also Beach of Kelapa in Patimban that suitable to be developed as a marine tourism area.

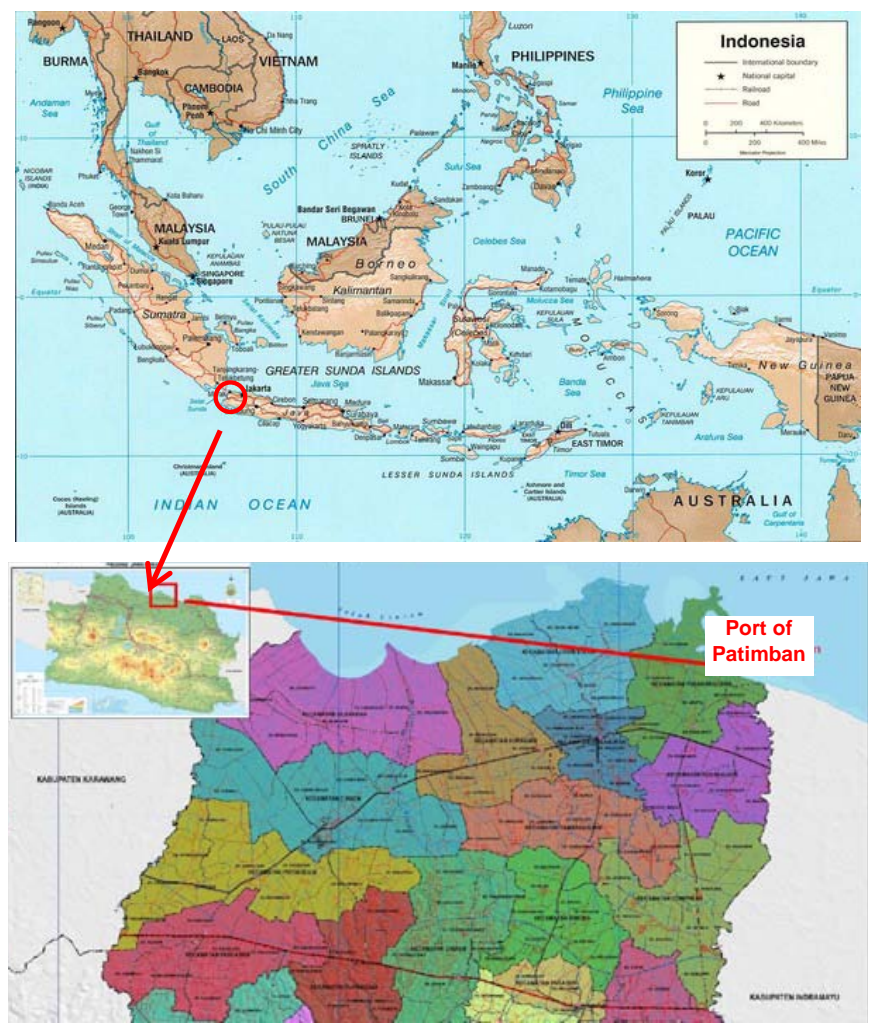

Figure 1. Location of Patimban Port

Economy of Subang in 2015 had increased compared to previous years. Its GDP growth rate in 2015 reached $5.29 \%$, while in 2014 was only 5.02\%. The highest growth was achieved by information and communication which amounted to $14.42 \%$. Economy of Subang regency is largely dominated by sector of agriculture, forestry, and fisheries. Subang as a granary and fruits producer in West Java illustrated that agriculture still to drive the regional economy. Nevertheless the role of agriculture sector tends to decrease and on the contrary industrial and commercial sectors tend to increase. The largest contribution to GDP in 2015 was agriculture, forestry, and fisheries $(27,89 \%)$ then followed by trade and vehicles repairing $(15,21 \%)$ and industry $(11,35 \%)$. 
Subang also contributed to the national economy which had grown stronger over the past decade along with trade policy and trade environment that progressively opened. Volume of export and import over the past few years showed a sharp increasing as a result of the port activities growth. Indonesia has two major port, i.e. Tanjung Priok and Tanjun Perak, which dominate import-export activities in Indonesia. Tg. Priok handled twothirds of trade and container traffic. Container traffic will grow faster but high dwelling time and payment system which is not optimal created port bottle necks. Therefore these problems should be overcome especially volume of containers flow to and from Indonesia will continue to increase. In addition, survey conducted by World Economic Forum in 2011, stated that major issue complained in the "Ease of Doing Business" in Indonesia is an imbalanced of infrastructure supply resulted in the movement of goods through ports being impaired. In Southeast Asia, Indonesia is among the countries left behind in terms of infrastructure development. Therefore, the government continued to push an effort for building port infrastructures in order to encourage local economic growth.

\section{Impact of Patimban Port Development}

Port of Patimban is appropriate as a cargo distribution center for the industrial zone surrounding Cikampek, Subang and Bandung by developing regional distribution center near such zones as apoke of pre-clearance \& customs clearance. Development international port as a hub distribution along the northern coast of java could be used to deploy manufacturing-Based industrial zones that would create new employments and increase economic growth of areas nearby. Distribution of goods from and to the several regional distribution centers in west java would be better because of many alternative modes of transport. Port of Patimban is expected to provide a nearest access from industrial regional centers and at the same time complementary to the new port of Tanjung Priok. Based on data of Indonesian Freight forwarding and Logistic Association, West Java province has the largest industrial zones in Indonesia, i.e. 31.5\% . Therefore, development of patimban port required supporting of of various parties. It is believed that this port could reduce logistic cost as closer to the centers of production centers and reduce fuel use, increase trucks utilization, strengthen economy resilience, reduce congestion and move partly of heavy freight traffic out of the capital, as well as ensure shipping safety. In the next few years, the growth of indutrial activities in West Java tends to increase along with the delopment of a number of national strategic infrastructure. However, many developers in the industrial zones are still waiting for further policy dealing with improvement of public transpor performance which is not quite ideal for people needs. Enhancement of public transport infrastructure including patimban port as an international port should be realized to match carrying capacity of trading activities so is expected to improve the port competitiveness.

\section{Container Throughput and Economic Development}

Port of Patimban is expected to be one of gates out for ships and goods both domestic and expor and import cargoes mainly for the industrial area in West Java. Besides, it will play an important role in cargoes distribution that have been equipped with loading and unloading facilities to and from ships until receiver warehouses. Lately, systems and procedures of ships services and containers loading and unloading process at several major ports are presumed to draw high costs. Therefore, involvement of all parties are needed to minimize the high costs so that exporters and importers will obtain facilities in carries on business at the port. They should make plan to facilitate all parties interest only to boost economic growth from container activities at port.

According to many observers of the national economy, Indonesia has experienced rapid economic growth during recent years, and export contributed a great deal to the region's economic development. According to UNCTAD Maritime Transport, the total fleet in South East Asia has increased from 58,280 vessels in 2002 to 150,337 in 2014. Along with its economy development, Indonesia's trade policies and trade environment have been rather progressively opened, which increased 9,32 \% and sharp increase of foreign direct invest in Indonesia during these years.

Indonesia has two principal ports, Tanjung Priok Port and Tanjun Perak Port, the former handling two-thirds of Indonesia's international trade and container traffic. And of those ports, port of Tanjung Priok accommodates about 65 percent of Indonesia's export activities. The flow of containers in Tanjung Priok has been increasing since the year 2010 to 2014 but has been repeatedly experiencing congestion and high dwelling time. Growth of containers flow will continue to increase along with national and global economies growth. Indonesian economic development (measured by GDP growth) for the $2010-2015$ period reached $4.63 \%$ per year, lower than the average growth in the years $2005-2010$ the value $18.45 \%$. Here is a picture of economic growth in Indonesia. 


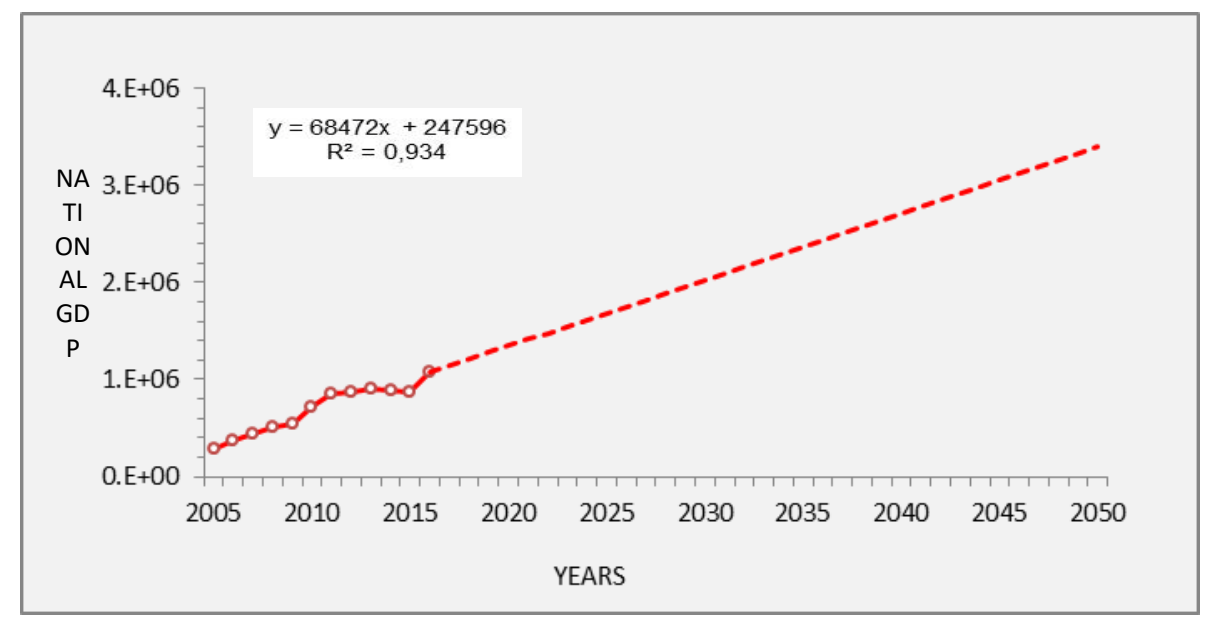

Source: Processed from UNCTAD dan World Bank data, 2016

Figure 2. Indonesian GDP Growth between 2005-2050

Indonesian Agency of National Development Planning estimated that in 2015 contributions of transport sectors to national GDP are highway (Rp. 463.058 billion), sea transport (Rp. 129.963 billion), air transport (Rp. 62.214 billion), inland waterway (Rp. 24.708 trillion) and rail transport (Rp. 4.965 trillion). Sea transport is the second largest contributor, i.e. $18.98 \%$ to nasinal GDP. Accordingly, role and function of the seaport is essential for economic growth today. That's why Indonesian ports should be developed to maintain economic growth. Container throughput forecast in Tanjung Priok would continue to increase, but appeared congestion and dwelling time that needed another adjacent port development and work together in order to accelerate port services and to get efficient logistics costs. Moreover, there are many industrial zones in West Java which coverage areas are quite large then needs to consider alernatif port that are closer to the zones. According to Indonesian chambes of Commerce and Industry, West Java has now become the heart of national industry because it controls more than 50 per cent industrial contribution sector to the national economy, and $\pm 74.2 \%$ of the domestic industry areas are in West Java.

Port of Tanjung Priok is currently rank of 23 with a container volume of 6.5 TEU. And with the inauguration of the first phase of new priok port, it will reach 7.5 million TEUs of 11.5 million TEU total volume capacity. Prediction of container volume as shown in this figure below, it seems that the capacity above would be not enough then needed to develop another port.

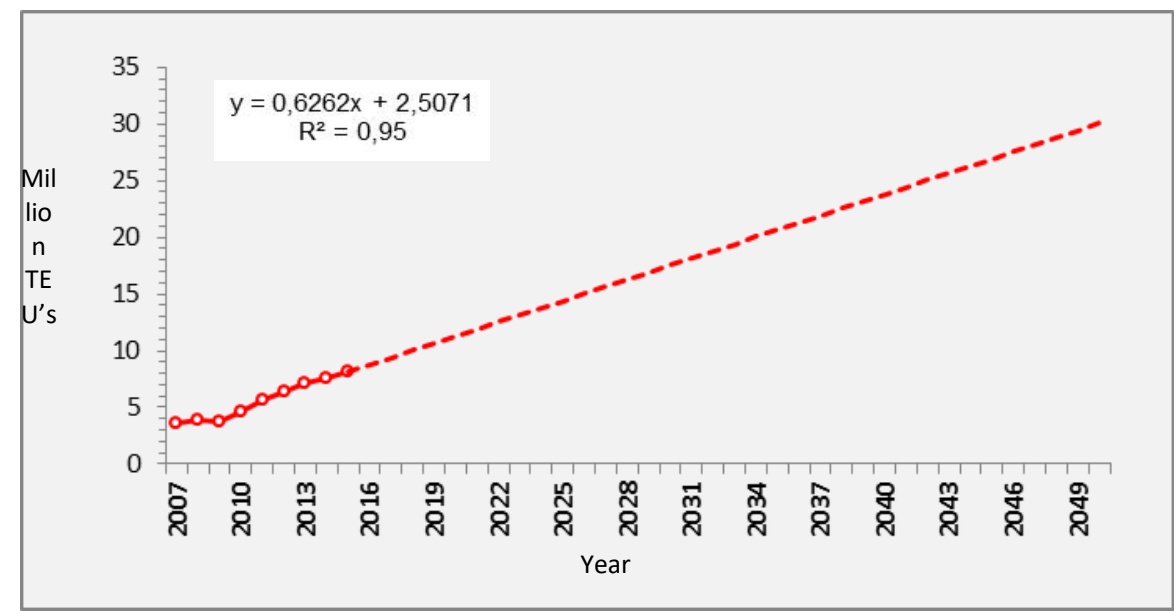

Figure 3. Container growth between 2007-2050

The above data shows an excess volume of cargo flows need to be diverted to other places in the northern coasts in order that the all potential freight could be properly handled. President considered alternative port needed to built in view of existing ports like Tanjung Priok, Tanjung Emas and Tanjung Perak are becoming congested. New port infrastructure needed to improve efficiency of transport and logistic costs. 


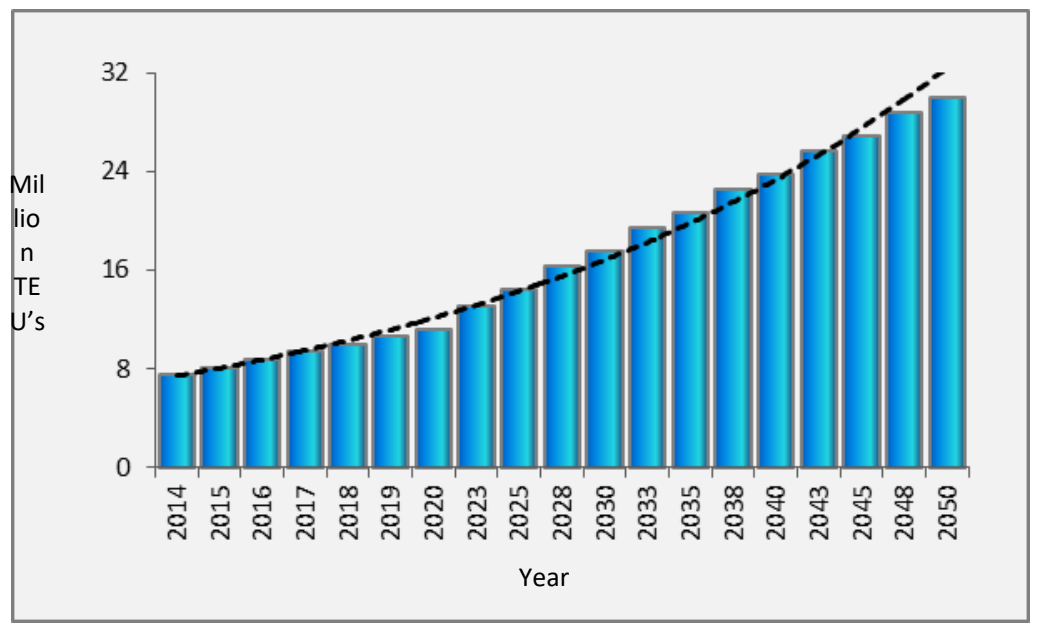

Figure 4. Container growth Forecast

Transportation Minister Decree No. 414/2013 stated Port of Subang as a regional feeder port, but this port has been upgraded as an international port to complete the function of Tanjung Priok Port. Its advantages are 10 meters water depth and will be dredged up to 14 meters, about $70 \mathrm{~km}$ from Cikarang industrial zone and $\pm 8 \mathrm{~km}$ from national road. To realize patimban as an international seaport, the existing port infrastructure is being developed further at the first phase in order to accommodate 250,000 cars, 1.5 million TEUs. This port is predicted to accommodate container capacity of 7.5 million TEUs and 500,000 vehicles.

\section{Transport Infrastructure Obstacles}

Infrastructures in Indonesia has become classic issues which their development were still considered minimal, but nevertheless government continues to make improvements in order to facilitate the potential possessed mainly by the province of West Java. Development of port infrastructure in Subang intended to allow the existing constraints could be minimized so that West Java could continue to contribute to the national economy in the industrial sector. West Java industrial sector that declined among others printing industry dropped 10.8\%, textile industry dropped $8.3 \%$, chemical industry $2.2 \%$, electrical equipment industry $2.2 \%$, etc. Other obstacles are congestion and dwelling time that complaints by port users. So far, dwelling time in Indonesia is much longer compared to other countries in Southeast Asia. Duration of dwelling time caused Indonesian competitiveness left behind other countries. Wahyu Septi Utami [16] mentioned that the unpreparedness of Tanjung Priok in anticipating growth of cargo flows because the infrastructure had not improved and resulted in increasing bottleneck.

As the largest archipelago country, Indonesia has an interest to establish a reliable marine transportation. National connectivity is quite well concept to help address the regional gap. Development of sea transport infrastructure networks would help to realize the increased of port connectivities so as to facilitate flow of cargo export and import. Therefore it is necessary accelerated development of the port that those obstacles could be overcome and port competitiveness port could be realized given the rank of our port infrastructure at the Asean level is still left behind neighbouring Asian rivals such as Singapore and Vietnam (see table 1), which have become ports of call for direct services to the US or Europe owing to their ability to handle larger vessels.

Tabel 1. Rank of Asean Port Infrastructures

\begin{tabular}{|r|l|r|r|r|}
\hline \multirow{2}{*}{ No } & \multirow{2}{*}{ Countries } & \multicolumn{3}{|c|}{ Year } \\
\cline { 3 - 5 } & & 2013 & 2014 & 2015 \\
\hline 1 & Singapore & 2 & 2 & 2 \\
\hline 2 & Malaysia & 24 & 16 & 16 \\
\hline 3 & Thailand & 56 & 52 & 52 \\
\hline 4 & Vietnam & 98 & 76 & 76 \\
\hline 5 & Indonesia & 89 & 82 & 82 \\
\hline 6 & Kamboja & 81 & 83 & 83 \\
\hline 7 & Philipine & 116 & 103 & 103 \\
\hline
\end{tabular}

Source: Global Competitiveness Report, 2013-2015 
Related to the performance of port infrastructure, there has been continuous improvement effort by the government but port service users assessed it is not maximum because co-ordination and communication between relevant agencies are still not optimum.Railroad to the port has been built but still considered not enough to reduce congestion to port of Tanjung Priok due to rapid growth of containers volume to and from the port. Currently, volume of cargo flows increases, rapid industrial zones development, and $70 \%$ of trades are conducted in Tanjung Priok. Therefore, it is necessary to seek an overhaul with addition of new ports that work together in handling volume growth of exports and imports of goods. Transport sector development reflected economic growth so that transport had an important and strategic role, both macro and micro. Success of the transport sector at the macro level could be seen from added value contribution in the establishment of Gross Domestic Product, the multiplier effect for other sectors and the ability to reduce rate of inflation through distribution of goods and services until remote areas. Therefore, the availability of reliable and sufficient transportation infrastructure are very important to be pursued, and invite private participation through public private partnership are certainly expected in realizing the availability of reliable and adequate transportation infrastructure. Infrastructure development is absolutely necessary, especially in the effort to improve economy of a region. Port infrastructure development would be able to facilitate economic activities and improve productivity and people income. The existence of port infrastructure would be able to give a positive and significant impact on productivity and economic growth which appeared in the income per capita of the community.

\section{CONCLUSION AND SUGGESTION}

\section{A. Conclusion}

1. Prediction result showed that although existing port like Tanjung Priok has been developed, it is rather difficult to cope with the increasing volume of container flows which started from 2035 will reach more than 25 million TEUs per year and therefore synergies with other port is a solution to meet the demand of container port terminal capacity.

2. Port of Patimban was developed to handle 7.5 million TEUs and would synergize with Tanjung Priok or other ports to meet the demand of container terminal capacity which is still not enough.

3. Problems of logistic and transport costs at seaport could be overcome by maximizing port efficiency so as the price of goods could be reduced, increasing productivity with supported by well port infrastructure and qualified human resources.

4. At present, about $65 \%$ volume of trading carried out in Tanjung Priok, so that needed to change pattern of cargoes handling by developing new port outlet closed to production centers in order to avoid stagnation, congestion and dwelling time.

\section{B. Suggestion}

1. Industrialization in West Java has been growing rapidly, but the existing ports are not enough to accommodate such growing. Therefore, commitment of all parties should be needed to anticipate the increasing flow of goods by building port infrastructure close to industrial zone in order to achieve more efficient logistics costs.

2. Acceleration of port development is required so that the main challenges come from the lack of port capacity could be addressed and the port competitiveness could be increased because the rank of national port infrastructure at ASEAN level is still left behind some neighbouring countries.

\section{REFFERENCES}

[1] Cas van der Baan et.al. 2015. State of Logistics Indonesia 2015. http://www.nestra.net/ download/StateofLogisticsIndonesia2015.pdf (diakses 5 november 2016).

[2] Vijay Hiranandani, 2012) Sustainable Development In The Maritime Industry: A Multi-Case Study of Seaports. World Economic Assiciation. www.rrojasdatabank.info/ Hiranandani.pdf (accessed on december 1, 2016).

[3] Marco Benacchio et.al. 2000. On the Economic Impact of Ports: Local vs. National Costs and Benefits. International Workshop. Genoa. June 8-10, 2000. http://www.informare.it/ news/forum/2000/sig2/genovaes.asp (acceseed on december 20, 2016).

[4] S. Islama and T.L. Olsena. 2011. Factors Affecting Seaport Capacity. 19th International Congress on Modelling and Simulation, Perth, Australia, 12-16 December 2011. http://mssanz.org.au/ modsim2011. (accessed on october 5, 2016).

[5] Greg Knowler. 2014. Vietnam and Indonesia Face Up to Port Capacity Issues. http://www.joc.com/port-news/vietnam-and-indonesiaface-port-capacity-issues_20140912. html (accessed on november 10, 2016). 
[6] Kompas Daily. 2016. This Morning, Jokowi Inaugurates Kalibaru Container Terminal in Tanjung Priok. September 13 , 2016. http://nasional.kompas.com/read/2016/09/13/07582221/ pagi.ini.jokowi.resmikan.terminal.peti.kemas.kalibaru.di.tanjung.priok. (accessed on Desember 5, 2016).

[7] Adris.A.Putra, Susanti Djalante. 2016. Development of Port Infrastructure in supporting sustainabel development. Scientific Journal of Media Engineering Vol.6 No.1, January 2016 (433-4) ISSN: 2087-9334.

[8] Goldi Evi Grace Simatupang. 2013. Maritime Connectivity: National Integration and Global Connectivity. Center for Defence and Maritime Studies. http://www.fkpmaritim.org/ konektivitas-maritim-integrasi-nasional-dan-keterhubungan-global/ (accessed on december 15, 2016).

[9] National Connectivity. 2011. Sustaining Partnership - Media of information on public private partnership. Special Edition.

[10] Wagijono. 2011. National Transport System Driving and Supporting All Sectors of Development. Journal of Shiiping and Port Applied vol. 1 No.2 Maret 2011. http://www.slideshare.net/ jibrinaddifia/2-sistem-transportasi-nasional-wagijono (accessed on december 10, 2016).

[11] James J. Laird, John Nellthorp, Peter J. Mackie. 2005. Network Effects and Total Economic Impact in Transport Appraisal. http://eprints.whiterose.ac.uk/2020/2/ITS13_ Network_effects_and_total_economic_impact_UPLOADABLE.pdf. (accessed on January 10, 2016).

[12] Haryo Aswicahyono and Deni Friawan. 2008. Infrastructure Development in Indonesia. Centre for Strategic and International Studies. http://www.eria.org/publications/ research_project_ reports/images/pdf/PDF\%20No.2/No.2-part2-5.Indonesia.pdf. (accessed on november 19, 2016).

[13] Syafi'i, Katsuhiko Kuroda, Mikio Takebayashi. 2005. Forecasting The Demand Of Container Throughput in Indonesia. Memoirs of Construction Engineering Research Institute Vol.47 (paper) Nov.2005.

[14] Oxfrod Business Group. 2015. Prioritising ports: The modernisation of ports is a prerequisite for economic expansion. https://www.oxfordbusinessgroup.com/analysis/ prioritising-ports-modernisation-ports-prerequisite-economic-expansion. ((accessed on november 30, 2016).

[15] Ofiar Z. Tamin, 2001. Concept of the Development of Regional Transport System in the Era of Regional Autonomy. An Article presented in national seminar held by Ministry of Internal Affairs and Agency of National Development Planning, Jakarta November 26, 2001.

[16] Wahyu Septi Utami. 2015. Dwelling Time Acceleration: Strategy for increasing international trading performance of Tanjung Priok Port. Journal of Economics Development Analysis. http://journal.unnes.ac.id/sju/index.php/edaj (accessed on november 10, 2016). 